\title{
Influence of Stationary and Bioreactor Cultivation on Lentinula edodes (Berk) Pegler Lignocellulolitic Activity
}

\author{
Magali Regina ${ }^{1}$, Fernando Broetto $^{1}$, Giovanni Giovannozzi-Sermanni ${ }^{2}$, Rosita \\ Marabotini $^{2}$ and Claudio Peranni ${ }^{2}$ \\ ${ }^{1}$ Department of Chemistry and Biochemistry, IB, São Paulo State University (UNESP), 18618-000 Botucatu, SP, \\ Brazil; broetto@ibb.unesp.br. ${ }^{2}$ Agrobiology and Agrochemistry Department, Tuscia University, via S. Camillo di \\ Lellis, s.n., 01100 Viterbo, Italy.
}

\begin{abstract}
This work aimed to study the stationary and periodically mixed culture of L. edodes to the production of lignocellulolitic enzymes activity. LE 95/17, LE 96/22 and Leax strains were incubated in $25 \mathrm{~g}$ of eucalyptus sawdust substrate in Erlenmeyer flasks in stationary culture at $25^{\circ} C$ and in a bioreactor with four complete rotations daily at $25^{\circ} \mathrm{C}$ and $3 \% \mathrm{CO}_{2}$. The samples were collected at $8,11,14,17$ and 20 days after the incubation. Oxidative and hydrolytic enzymes analyses were performed. Lignin peroxidase enzyme was not found in the lignolytic system for LE 95/17, LE 96/22 and Leax strains in the different incubation methods. The use of bioreactor could be a practicable system to induce the laccase activity for L22 and Leax and MnP activity for L17 and L22. The activity of the hydrolytic enzymes was higher in the stationary system in comparison to periodically mixed system in the bioreactor.
\end{abstract}

Key words: Shiitake, enzymes, agricultural residues

\section{INTRODUCTION}

From the chemical point of view, lignin is a macromolecule constituted by the phenylpropanoid units, which are bound through several covalent bonds. Due to the types of bond and their heterogeneity, lignin can not be broken by the hydrolytic enzymes as most of other natural polymers (cellulose, starch, proteins) (Hofrichter, 2002). During the evolution, only a group of organisms, the basidiomycetes, has developed the capacity of substantially degrading the lignin, mineralizing it to carbon dioxide (Hatakka, 1994). The three major groups of lignin modification enzymes produced by the fungi are: laccase, manganese peroxidase $(\mathrm{MnP})$ and lignin peroxidase (LiP) (Kirk and Farrell, 1987; Boominathan and Reddy, 1992; Hatakka, 1994; Thurston, 1994). Some white-rot fungi produce all these enzymes while others produce one or two of them (Hatakka, 1994). The ability to synthesize the $\mathrm{MnP}$ is found in particular taxonomic group of the basidiomycetes (Cairney and Burke, 1998), typical wood colonizers from Meruliaceae, Coriolaceae and Polyporaceae families, as well as soil colonizers from Strophariaceae and Tricholomataceae families (Hofrichter, 2002).

The fungal enzymes are shown to be useful in the degradation of a persistent variety of the environmental pollutants. A number of these

\footnotetext{
${ }^{*}$ Author for correspondence
} 
enzymes are extra-cellular and in nature, they are probably involved with wood degradation (Mayer and Staples, 2002). Studies carried out under liquid culture corroborated degradation of 2, 4, 6trichlorophenol by the white-rot fungi Panus tigrinus and Coriolus versicolor. In P. tigrinus cultures, it was predominantly catalyzed by the $\mathrm{MnP}$ while in $C$. versicolor, by the laccase, suggesting that the regulation of these enzymes was different in these two fungi (Leontievsky et al., 2000). The bioremediation of industrial effluents has also been investigated using whiterot fungi. One study evaluated the fungi capacity for bleaching and decontamination of effluents. The enzymes found in this case were mostly represented by the presence of laccase, $\mathrm{MnP}$ and LiP, once again corroborating these enzymes potential (Mayer and Staples, 2002).

Many studies have been directed to the development of more productive microbial strains while others concentrated on improving the fermentation processes (Esterbauer et al., 1991; Haltrich et al., 1996).

Among several kinds of biomass materials, lignocellulosic has been considered an optimistic one due to its abundance, low cost and high viability potential. Solid-state fermentation (SSF) offers advantages over liquid fermentation or submerged (SmF). Many publications describe the production viability of industrially important enzymes such as protease, cellulase, xylanase, pectinase, amylase, glucoamylase, etc. in SSF using agricultural byproducts (Pandey et al., 1999). According to Bellon-Maurel et al. (2003), in the last 30 years, solid-state fermentation has been studied in laboratories an pilot scale, for a number of applications such as silage, biomass and metabolites production using organic substrate and inert supports. The main parameters to be measured and controlled in the solid-state fermentation process are: temperature, homogenous aeration, $\mathrm{pH}$ and water content. The design of the bioreactors posses complexity in SSF due to the problems to monitor and control the environmental aspects, biomass and/or metabolic production (Bellon-Maurel et al., 2003). The rotary drum bioreactors (RDR) have a horizontal or inclined cylindrical drum and agitation is done by a central axis rotation system or by the spades inside the drum. The conditions allow aseptic fermentation, soft mixture, a possible automation, and low heat removal (Han and Anderson, 1975; Hesseltine, 1977; Lonsane et al., 1985).
The strong relation among the incubation conditions, substrate and enzymatic activity defines the importance of a deeper research on Lentinula edodes enzymatic activity. The present work aimed to study the influence of the stationary culture and bioreactor on L. edodes lignocellulosic enzymatic activities.

\section{MATERIALS AND METHODS}

\section{Lentinula edodes strains acquisition and substrate preparation}

LE 95/17 (L17), LE 96/22 (L22) and Leax de $L$. edodes strains were provided by Modulo de Cogumelos da UNESP - Botucatu, SP, Brazil. This substrate in both the incubation forms was made with $79 \%$ of eucalyptus sawdust, $20 \%$ of rice bran, $1 \%$ of $\mathrm{CaCO}_{3}$ and moisture content was adjusted to $60 \%$.

\section{Experiment in stationary system}

The substrate $(25 \mathrm{~g})$ was weighed and transferred to $250 \mathrm{~mL}$ Erlenmeyer flasks and sterilized in autoclave at $120^{\circ} \mathrm{C}(1 \mathrm{~atm})$ for 30 minutes. The liquid inoculum was prepared with the strains previously grown in a test tube, totally covered by the mycelium and mixing it by an Ultra-Turrax (IKA-Werk, Darmstadt Germany) for approximately 10 seconds. Each Erlenmeyer flasks was inoculated with $3 \mathrm{~mL}$ liquid inoculum and closed with a cotton cover. Afterwards, the flasks were slightly mixed in a circular Erlenmeyer movement only once and kept in an incubation chamber in dark conditions at $25^{\circ} \mathrm{C}$. Lignocellulosic enzyme activity was determined at $8,11,14,17$ and 20 days after incubation. For each observation period and strain, three replicates were made. The experimental design used was entirely randomized.

\section{Experiment in bioreactor}

The substrate was prepared as above with $6.396 \mathrm{~g}$ for each treatment and transferred to a rotatory drum reactor (RDR) (Figure 1), with $20 \mathrm{~L}$ volume, and autoclaved at $120^{\circ} \mathrm{C}(1 \mathrm{~atm})$ for $1 \mathrm{~h}$ and $30 \mathrm{~m}$. After cooling, each reactor received $300 \mathrm{~mL}$ of inoculate liquid from each strain. The rotary drum reactors were programmed to perform four rotations day ${ }^{-1}$. Each movement was $1 / 6$ of reactor (total of 24 movements a day ${ }^{-1}$ ) in a $5.5 \mathrm{~cm} \mathrm{~s}^{-1}$ velocity. Gaseous phase was monitored by an 
oxygen paramagnetic analyzer and by a carbon dioxide infra-red detector (Model Beckman 860, United Kingdom). $\mathrm{CO}_{2}$ concentration was kept constant at $3 \%$ at $25{ }^{\circ} \mathrm{C}$. Samples of $25 \mathrm{~g}$, from each reactor, were withdrawn at $8,11,14,17$ and $20^{\text {th }}$ days after the inoculation.

\section{Enzymatic extraction}

For enzyme extraction, $80 \mathrm{~mL}$ of sodium acetate buffer $(50 \mathrm{mM}, \mathrm{pH} 5.0)$ was added to the Erlenmeyer which was kept in shakers with orbital rotation $(50 \mathrm{rpm})$ for one hour. The suspension was filtered $(40-100 \mu \mathrm{m})$ and the extract was used to determine the enzymatic activity. After the extraction, the substrate was dried at $105^{\circ} \mathrm{C}$ until constant weight to determine its dry weight.

\section{Lentinula edodes oxidative enzymes activity analysis}

The laccase activity was spectrophotometrically determined by using 2,6-dimetoxiphenol (DMOP) as substrate (Slomczynski et al., 1995). Total volume of reaction $(1 \mathrm{~mL})$ was composed by 2 $\mathrm{mM}$ DMOP in acetate buffer $(0.1 \mathrm{M}, \mathrm{pH} 4.2)$ and
$5 \mu 1$ sample. DMOP oxidation was followed by the kinetics at $30^{\circ} \mathrm{C}$ at $477 \mathrm{~nm}\left(\varepsilon_{477}=14600 \mathrm{M}^{-1} \mathrm{~cm}^{-1}\right)$. The manganese peroxidase activity $(\mathrm{MnP})$ was determined by Waarishi et al. (1992) method. The reaction volume $(1 \mathrm{~mL})$ was composed $0.1 \mathrm{mM}$ $\mathrm{MnSO}_{4} ; 10 \mu \mathrm{l}$ sample in malonate buffer $(50 \mathrm{mM}$, $\mathrm{pH} 4.5$ ) and $75 \mu \mathrm{M}$ hydrogen peroxide. Chelate complex formation of $\mathrm{Mn}(\mathrm{III})$-malonate was followed by the kinetics at $30{ }^{\circ} \mathrm{C}$ for 1 minute, measuring the absorbance increase at $270 \mathrm{~nm}$ $\left(\varepsilon_{270}=11590 \mathrm{M}^{-1} \mathrm{~cm}^{-1}\right)$.

For the lignin peroxidase determination (LiP), veratrilaldehyde formation was used $(3,4$ dimetoxibenzaldehyde) Hatakka (1994). The reaction volume $(1 \mathrm{~mL})$ was composed $0.4 \mathrm{mM}$ of veratril alcohol in tartrate buffer $(0.1 \mathrm{M}, \mathrm{pH} 3.0)$; $0.2 \mathrm{mM}$ of $\mathrm{H}_{2} \mathrm{O}_{2}$ and the sample. The activity was followed by kinetics at $30^{\circ} \mathrm{C}$, measuring the absorption at $310 \mathrm{~nm}\left(\varepsilon_{310}=9300 \mathrm{M}^{-1} \mathrm{~cm}^{-1}\right)$. All the enzymatic determinations were performed with three replications per treatment.

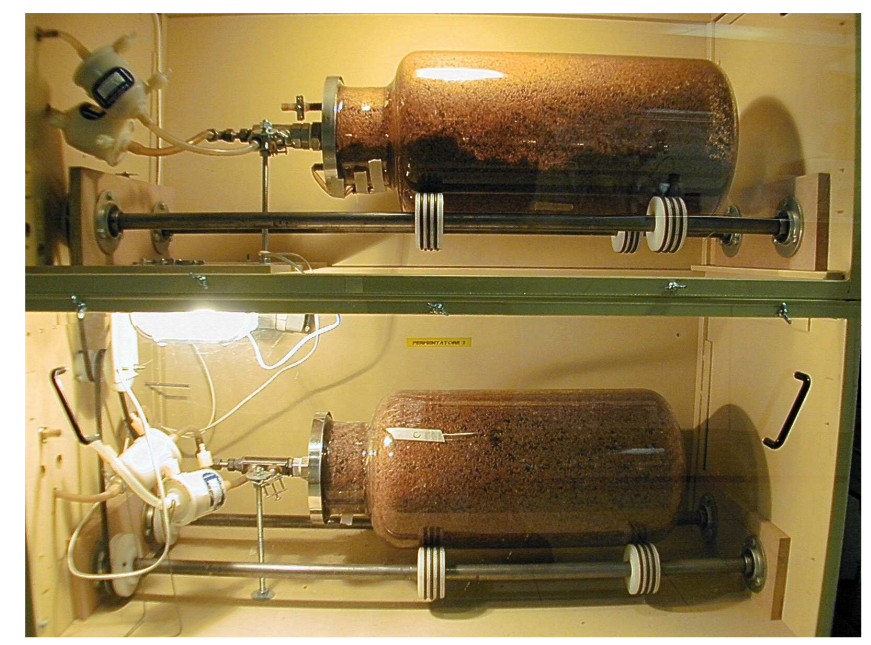

Figure 1 - Bioreactor used for the liquid culture of L. edodes

\section{Lentinula edodes hydrolytic enzymes activity analysis}

The hydrolytic enzymes analysis was performed according to Nelson modified method (1994). The enzymatic substrate was prepared in acetate buffer (50 mM, pH 5.0) as follows: Xylan for endo-1,4- $\beta$-xylanase activity (xylanase, EC 3.2.1.8): $0.25 \mathrm{~g}$ of xylan in $100 \mathrm{~mL}$ acetate buffer. Soluble starch for $\alpha$-amylase activity (amylase): $0.5 \mathrm{~g}$ in $100 \mathrm{~mL}$ acetate buffer. Carboxymethyl cellulose for endo$1,4-\beta$-glucanase activity (carboxymethyl cellulase, CMCase, EC 3.2.1.4): $1 \mathrm{~g}$ in $100 \mathrm{~mL}$ acetate 
buffer. Microcrystalline cellulose for exo-1,4- $\beta$ glucanase activity (FPase, EC 3.2.1.91): $0.5 \mathrm{~g}$ in $100 \mathrm{~mL}$ acetate buffer. Pectin for pectinase activity: $0.24 \mathrm{~g}$ in $100 \mathrm{~mL}$ acetate buffer $+0.12 \mathrm{M}$ $\mathrm{NaCl}+6 \mathrm{mM}$ EDTA. The equation for determining hydrolytic enzymes activity based on straight line was:

$\mathrm{C}_{\mu \mathrm{g} . \mathrm{mL}}{ }^{-1}=[($ Abs sample - Abs white $)-0.0049] /$ $0.002 \times$ dilution factor and UI.mL ${ }^{-1}=\left(\mathrm{C}_{\mu \mathrm{g} / \mathrm{mL}}-\right.$ intrinsic value) / substrate molecular weight/ incubation minutes (10 min.)

\section{Statistical Analysis}

Statistical methodology used for data evaluation followed a non-linear regression model. For the comparison of the parameters, non-parametric variance analysis with application of KruskalWallis test was applied. In cases in which significant difference was present, the StudentNewman-Kills (SNK) test was applied with $5 \%$ significance level.

\section{RESULTS AND DISCUSSION}

Lentinula edodes oxidative enzymes activity determination in stationary system

The MnP and laccase activities where detected in different substrates in the stationary system. LiP did not show a perceivable activity. A more significant laccase activity was observed on $8^{\text {th }}$ and $14^{\text {th }}$ day (Figure 2, upper graph). After the $14^{\text {th }}$ day, the activity decreased until the end of the incubation in all the strains without a significant difference. The higher activity was observed in L17 on $8^{\text {th }}$ day of incubation.

$\mathrm{MnP}$ activity was maximum to L17 and Leax on $11^{\text {th }}$ day. After this period a significant decrease in the activity occurred. However, for L22, the MnP activity significantly increased from $14^{\text {th }}$ day until the end of incubation.

\section{Lentinula edodes oxidative enzymes activity determination in bioreactor}

For this experiment, only eucalyptus sawdust was used, and distinct behavior in laccase and $\mathrm{MnP}$ production was observed (Figure 2, lower graph). Laccase activity in L17 showed statistically lower levels compared to Leax and L22, and on $14^{\text {th }}$ day, its activity was no longer detected.

In Leax, laccase activity after the $8^{\text {th }}$ day decreased and remained low until the end of the incubation.

The Leax strain from $8^{\text {th }}$ to $11^{\text {th }}$ day did not show significant difference in the MnP activity, however it was significantly higher when compared to the stains L17 and L22. The Leax strain showed a decrease in activity on the $14^{\text {th }}$ day and remained low until the end of incubation. The strain L22 showed its maximum activity on thet $14^{\text {th }}$ day with a significant decrease in activity on the $17^{\text {th }}$ day, until the end of incubation. The strain L17 on the $14^{\text {th }}$ day showed a significant activity decrease but on the $17^{\text {th }}$ day it increased again and which win maximum activity. It showed a significant decrease by the end of incubation.

The laccase activity in the bioreactor for the strain L22 showed similar characteristics as for the stationary culture system except for the end of incubation. For the L17 this activity was lower in the bioreactor. For the strain Leax, laccase activity was more uniform in this system. All $L$. edodes strains showed $\mathrm{MnP}$ activities higher on the $8^{\text {th }}$ day of the incubation in the bioreactor system. For the Leax strain after this period and until the end of incubation $\mathrm{MnP}$ activity was significantly lower. This was not observed during incubation in the stationary system. For the L22, a higher MnP activity was observed in the bioreactor compared to the stationary system, except at the end of incubation. $\mathrm{CO}_{2}$ and $\mathrm{O}_{2}$ control in the SSF for fungi of white-rot is considered a factor that interferes on enzyme production for the lignin degradation (Reid and Seifert, 1981; White and Boddy, 1992; Giovannozzi et al., 1996).

Similar to the stationary system, laccase activity in the bioreactor was lower when compared to MnP activity. According to Bollag and Leontievsky (1984) basidiomycetes generally produce low amounts of laccase. Furthermore, laccase production may be influenced by the nitrogen concentration in the culture media. Many times, high levels of nitrogen are required to increase the laccase development (Gianfreda et al., 1999). Fenice et al. (2003) reported that the highest MnP and laccase activities in $P$. tigrinus in RDR bioreactor occurred when $\mathrm{CO}_{2}$ concentration was 3 and $5 \%$ respectively. 


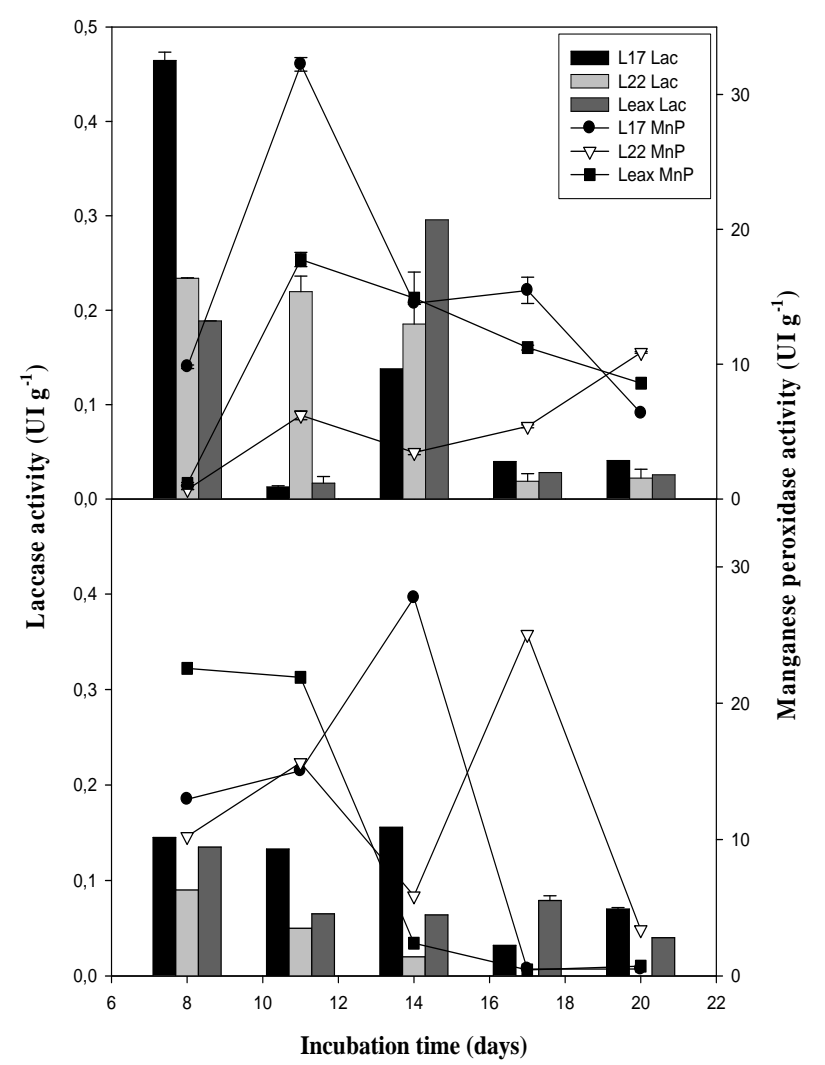

Figure 2 - Laccase and MnP activity of L. edodes strains (L17, L22 and Leax) in eucalyptus sawdust during growing period in stationary (upper graph) and bioreactor (lower graph) systems. Vertical bars represent median standard deviation $(n=3)$

\section{L. edodes hydrolytic enzymes activity determination in stationary system}

The amylase activity ( $\alpha$-amylase) on the $8^{\text {th }}$ day of incubation did not show statistical difference between the strains. On the $17^{\text {th }}$ day, strain Leax showed maximum activity (Figure 3 ). The strains did not show statistical difference for the FPase activity (exo-1,4- $\beta$-glucanase) until the $14^{\text {th }}$ day of incubation where L22 showed the highest activity. On $17^{\text {th }}$ day, the Leax showed a significantly lower activity compared to L17 and L22 which had statistically equal activities. On $20^{\text {th }}$ day, the Leax strain had a statistically similar activity to L17.

The xylanase (endo-1,4- $\beta$-xylanase) activity was statistically distinct between the strains, except on the $11^{\text {th }}$ day between L17 and Leax; and on the $17^{\text {th }}$ day between L17 and L22. All the strains expressed maximum activity on the 17th day of incubation, with the highest activity showed by the Leax on the $20^{\text {th }}$ day.

The CMCase (carboxymethyl cellulase) activity between the strains was statistically different during the whole process of incubation, except for the $8^{\text {th }}$ day between the Leax and L22, and on the $17^{\text {th }}$ day between L17 and Leax. Leax showed maximum activity of CMCase on the $17^{\text {th }}$ day compared to the other strains.

During the incubation, strains showed a statistically different pectinase activity, except on the $14^{\text {th }}$ day when activities had no significant difference among them. L17 began with its maximum pectinase activity and after that it 
slightly decreased, while Leax had maximum activity on the $17^{\text {th }}$ day.

\section{Determination of $L$. edodes hydrolytic enzymes activity in bioreactor}

The amylase activity between the strains during the incubation in bioreactor was statistically different, except on the $14^{\text {th }}$ day when L17 and Leax showed the same activity. L17 expressed a constant higher activity in comparison to the Leax and L22 (Figure 4).

The FPase activity was statistically distinct except on the $8^{\text {th }}$ day between the Leax and L22. L17 maintained FPase activity from $8^{\text {th }}$ to $17^{\text {th }}$ day without statistical difference, with a decrease at the end.

The xylanase activity for the L17 showed a constant without statistical difference with the strain Leax until the $11^{\text {th }}$ day. L17 showed a higher xylanase activity, from the $17^{\text {th }}$ day of the incubation. L22 showed low xylanase activity comparing to L17 and Leax, except on the $14^{\text {th }}$ day when it did not differ from the Leax.
The CMCase activity also occurred with a significant difference between the strains, except on the $14^{\text {th }}$ and $20^{\text {th }}$ day. Leax began with the higher CMCase activity related to L17 and L22 and reached its highest peak on the $11^{\text {th }}$ day.

The pectinase activity showed a statistical difference between the strains on the $14^{\text {th }}$ day. At this incubation point, the Leax showed its highest activity and remained until the end of incubation with significantly higher activities compared to L17 and L22

In the L17, the activities of all the enzymes were more stable during the whole incubation period when incubated in bioreactor rather than in a stationary system. The pectinase and amylase were the enzymes with the best results for this strain. In the Leax, CMCase was initially statistically equal to pectinase. During the whole incubation period the CMCase activity was higher to the FPase. The pectinase, amylase and CMCase were the best acting enzymes in the Leax. In the L22, pectinase also had a constant activity, followed by amylase activity. The FPase had rather low values compared to the rest of the enzymes.
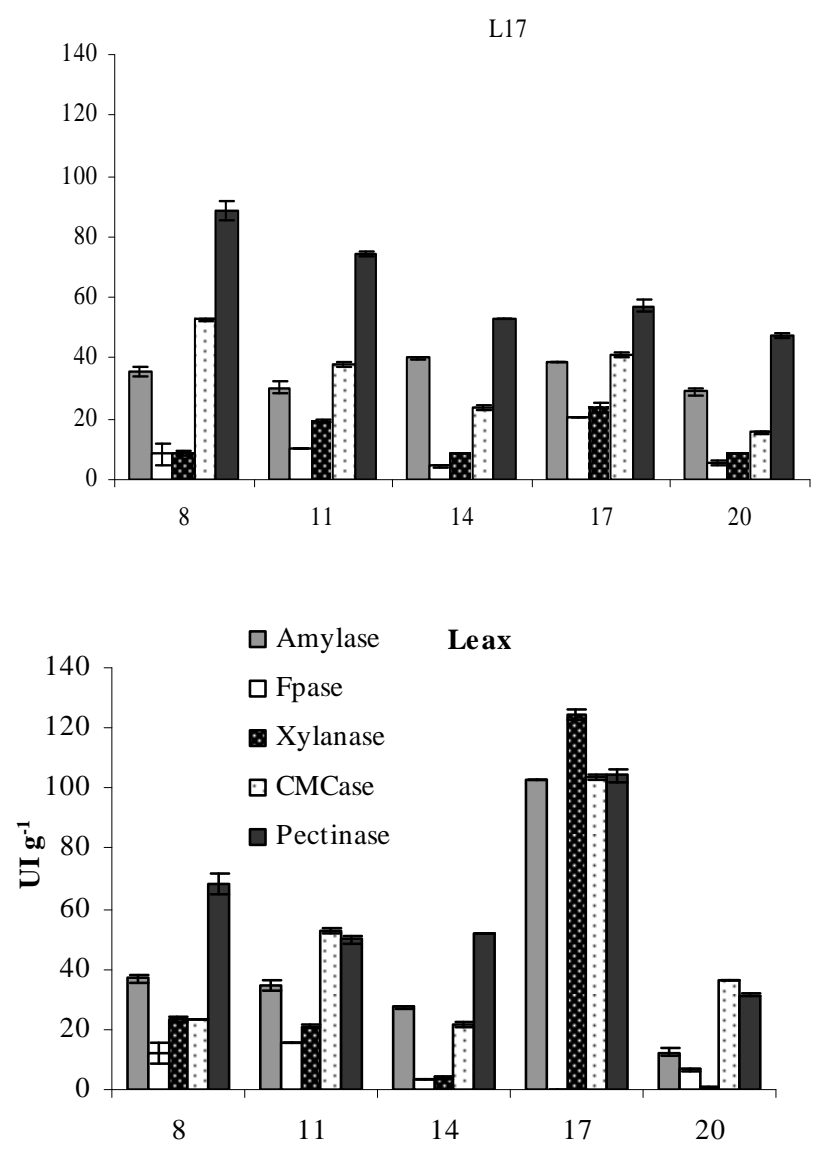


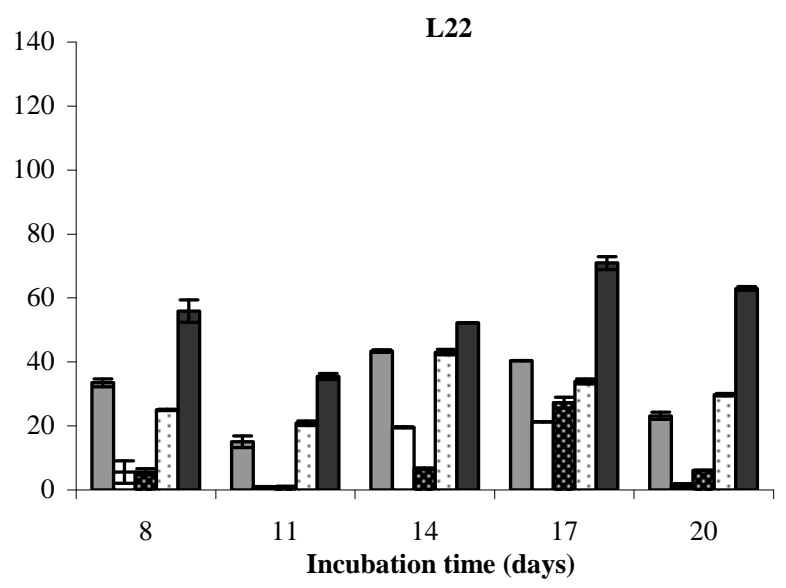

Figure 3 - Hydrolytic enzymes activities of L. edodes strains (L17, L22 and Leax) in eucalyptus sawdust during growing period under stationary system. Vertical bars represent median standard deviation $(\mathrm{n}=3)$
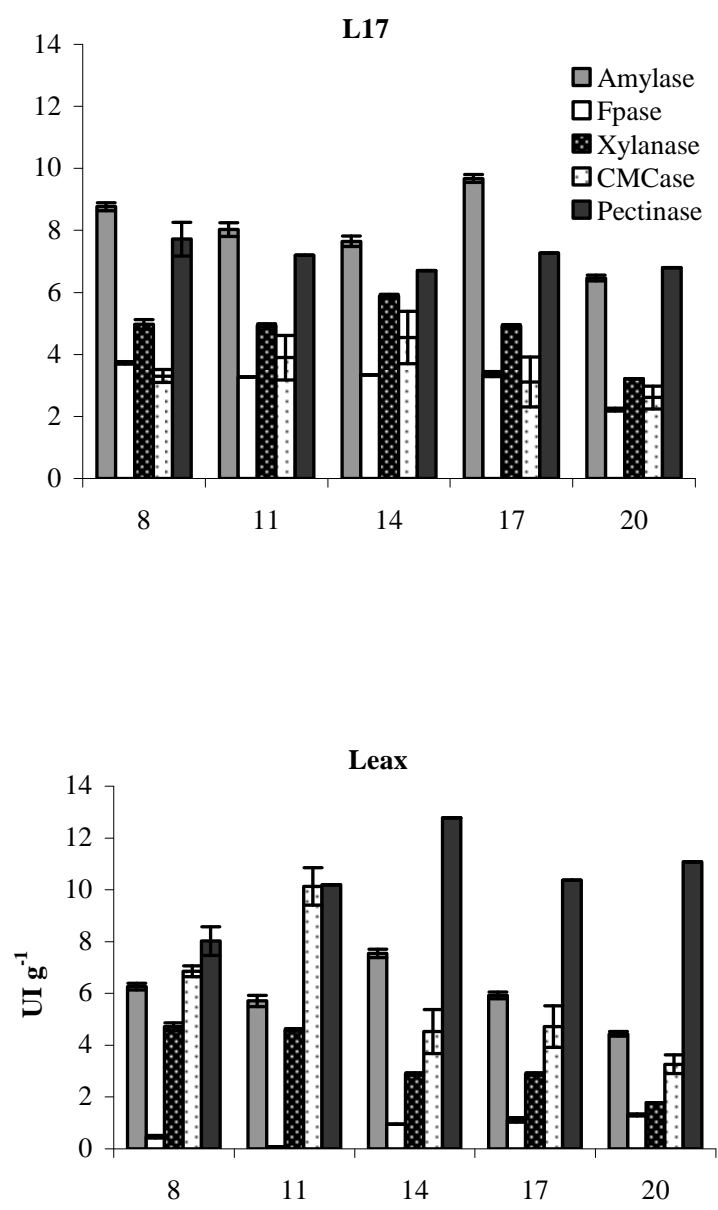


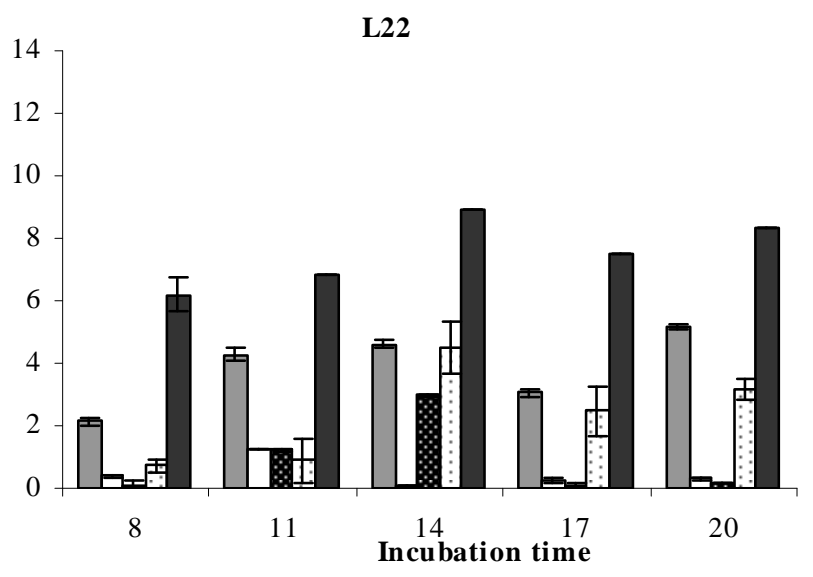

Figure 4 - Hydrolytic enzymes activities of L. edodes strains (L17, L22 and Leax) during growing in bioreactor. Vertical bars represent median standard deviation $(n=3)$

The results for hydrolytic enzymes activity in the bioreactor showed a decrease related to values observed in the stationary system. The factors which could be related to this decrease in the activity, among others, would possibly be: aeration and mixing rate. Techapun et al. (2003) verified this fact in a study performed with Streptomyces sp., incubated with a constant mixing rate and variation of aeration rate. The authors concluded that increased aeration rate significantly lowered the xylanase activity. When aeration and mixing rates varied, there was a reduction in xylanase activity due to high aeration and mixing rates.

Changes in the fungi morphology with the mixing, could be an explanation for results obtained in the present study which has been suggested by others also based on the microscopic analysis in Penicillium janthinellum and Paecilomyces sinclairii subjected to the effects of different agitation rates (Palma et al., 1996; Cho et al., 2002).

In the present study, each movement done by the bioreactor ( 24 movements, $5.5 \mathrm{~cm} \mathrm{~s}^{-1} \mathrm{dia}^{-1}$ ) would generate a mycelium disorganization. Aeration rate used $(3 \%)$ may also contributed to the results found. Possibly, if the incubation period was longer, would have been observed a higher hydrolytic enzymes activity

Adverse results were noted by Abd El-Nasser et al.(1997) studying Phanerochaetae chrysosporium incubation in a liquid medium, performed in stationary system and under agitation. The incubation under agitation results a slight increase of xylanase, glucanase and cellulase activities, when substrate such as sugar cane bagasse, corn cob and wheat straw were used.

Ohga and Royse (2001) observed a low cellulase activity related to laccase during $L$. edodes mycelium growth in eucalypt sawdust but this relation reversed after the substrate formed the mycelium cover and the first beginnings appeared. Dekker et al. (2001), in their studies on Botryosphaeria sp., observed that xylanase showed a higher enzymatic activity, compared to pectinase, FPase, CMCase and amylase. The cellulose source used did not influence the CMCase activity but low rates of FPase activity were found.

Watanabe (2002) suggested that molecular mechanisms which regulated the genetic expression of the enzymes during the incubation under solid state could be rather complicated. According to the author, genes of expression isolation and changes in cytoarchitecture and secretion mechanisms of fibrous fungi are necessary conditions to control the production of specific enzymes in SSF. Furthermore, Fenice et al. (2003) observed different values of enzymatic activity during the incubation of $P$. tigrinus in different types of the bioreactors. The authors concluded, among several things, that incubation model alter the enzymatic system. 
In the experiment with hydrolytic enzymes, the difference of the enzymatic activity was much more significant compared to the stationary system, while in the experiment with the laccase and $\mathrm{MnP}$ activities there were different points depending on the studied lineage and incubation model.

According to Raghavarao et al. (2003), the bioreactor is the heart of fermentation process where raw material, under suitable conditions, is converted into the desired product. The maximization rate of the product formation and yield in the bioreactor is part of the production optimization process. Many factors may affect the bioreactor performance such as the amount of substrate, moisture content in the substrate, aeration and temperature regulation, among others. Another aspect that although has not been the aim of this study, but deserves to be highlighted, is the substrate recovering time by the mycelium, observed during the experiment in the bioreactor. With incubation during 15 days, $6.396 \mathrm{~kg}$ of substrate was evenly colonized after being withdrawn from the bioreactor, substrate was placed in plastic bags and mycelium covering was formed in seven days.

The enzymatic activity in the bioreactor was not higher to the one observed in the stationary system, with some exceptions. Them, the fast substrate covering was probably due to factors such as the agitation and aeration.

The development of a simpler bioreactor, with low cost, higher substrate usage capacity and the selection of more adapted strains to this kind of incubation could increase the mushroom production in the country. Furthermore, the production uniformization and a shorter cultivation period would be essential for mushroom commercialization.

Brazil has a high agricultural sub products spectrum to be scientifically exploited, both to convert them into food or to produce important metabolites in several industrial sectors and the environment. The characterization of White-rot fungi, especially the mushroom production could be useful.

In conclusion, L. edodes strains L17, L22 and Leax showed a higher MnP activity than to laccase no matter what kind of incubation was used. Lip was not detected in L17, L22 and Leax strains in different forms of incubation. The Bioreactor was a suitable system to induce the laccase activity for L22 and Leax and in MnP activity for L17 and
L22. The cultivation under the stationary system allowed a higher hydrolytic enzyme activity related to the bioreactor.

\section{ACKNOWLEDGMENTS}

M.R. thanks CNPq and CAPES for award scholarship

\section{RESUMO}

Lentinula edodes pertence ao grupo de fungos causadores da podridão branca, conhecidos pela capacidade efetiva de degradar compostos lignocelulósicos. No cultivo deste fungo o método de incubação, substratos e características genéticas determinam o comportamento enzimático. Este trabalho teve como objetivo verificar a influência do cultivo estacionário e em bioreator na atividade de enzimas lignocelulolíticas do $L$. edodes. As linhagens LE 95/17, LE 96/22 e Leax foram cultivadas em $25 \mathrm{~g}$ de substrato composto de serragem de eucalipto em frascos de Erlenmeyer, em cultura estacionária, sob de temperatura controlada a $25^{\circ} \mathrm{C}$ e em bioreator com quatro rotações diárias e completas, a $25^{\circ} \mathrm{C}$ e $3 \%$ de $\mathrm{CO}_{2}$. Foram coletados dados aos 8, 11, 14, 17 e 20 dias depois da incubação para atividade de enzimas oxidativas e hidrolíticas. A enzima lignina peroxidase não foi encontrada em nenhum dos tratamentos. O uso de bioreator pode ser visto como um sistema praticável para induzir atividade de laccase para L22 e Leax e atividade de MnP para L17 e L22. A atividade de enzimas hidrolíticas foi maior no sistema estacionário em comparação com o sistema misturado periodicamente em bioreator.

\section{REFERENCES}

Abd el-nasser, N. H.; Helmy, S. M.; El-gammal, A. A. (1997), Formation of enzymes by biodegradation of agricultural wastes with rot fungi. Polymer degradation and stability, 55, 249-255.

Bellon-maurel,V.; Orliac, O.; Christen, P. (2003), Sensors and measurements in solid state fermentation: a review. Process Biochemistry, 38, 881-896. 
Bollag J.M.; Leonowickz, A. (1984), Comparative studies of extracellular fungal laccases. Applied Environmental Microbiology, 48, 849-854.

Boominathan, K.; Reddy, C. A. (1992), Fungal degradation of lignin: biotechnological applications, in: Arora, D.K., Bharat, R., Mukerji, K.G., Knudsen, G. (Eds.) Handbook of applied mycology. Fungal biotechnology, Marcel Dekker Inc., New York: 4, pp. 763-822.

Cairney, J. W. C; Burke, R. M. (1998), Do ecto- and ericoid mycorrhizal fungi produce peroxidases activity. Mycorrhiza, 8, 61-65.

Cho, Y. J. et al. (2002), Effect of carbon source and aeration rate on broth rheology and fungal morphology during red pigment production by Paecilomyces sinclairii in a batch bioreactor. Journal Biotechnological, 95, 13-23.

Dekker, R. F. H. et.al. (2001), A new role for veratryl alcohol: regulation of synthesis of lignocellulosedegrading enzymes in the lignolytic ascomyceteous fungus, Botryosphaeria sp.; influence of carbon source. Biotechnology Letters, 23, 1987-1993.

Esterbauer, H. et al. (1991), Production of Trichoderma cellulase in laboratory and pilot scale. Bioresource Technology, 36, 51-65.

Fenice, M. et al. (2003), Submerged and solid-state production of laccase and Mn-peroxidase by Panus tigrinus on olive mill wastewater-based media. Biotechnology, 100, 77-85.

Gianfreda, L.; Xu, L.; Bollag, L. M. (1999), Laccases: a useful group of oxidoreductive enzymes. Bioremediation Journal, 26, 1-25

Giovannozzi S. G. et. al. (1996), The production of exoenzymes of Lentinus edodes and Pleurotus ostreatus and their use for upgrading corn straw. Bioresource Technology, 48, 173-178.

Haltrich, D. et al. (1996), Production of fungal xylanases. Bioresource Technology, 58, 137-161.

Han, Y. W.; Anderson, A. W. (1975), Semisolid fermentation of ryegrass straw. Applied Microbiology, 30, 930-934.

Hatakka, A. (1994), Lignin-modifying enzymes from selected white-rot fungi: production and role in lignin degradation. FEMS Microbiology Review, 13, 125135.

Hesseltine, C. W. (1977), Solid sate fermentation. Process Biochemistry, 12, 29-32.

Hofrichter, M. (2002), Review: lignin conversion by manganese peroxidases (MnP). Enzyme and Microbial Technology, 30, 454-466.
Kirk, T. K.; Farrell, R. L. (1987), Enzymatic "combustion": The microbial degradation of lignin. Annual Review of Microbiology, 41, 465-505.

Leontievsky, A. A. et al. (2000), Transformation of 2,4,6- trichlorophenol by the white rot fungi Panus tigrinus and Coriolus versicolor. Biodegradation,11, 331-340.

Lonsane, B. K. et al. (1985), Engineering aspects of solid state fermentation. Enzyme Microbiology Technology, 7, 258-265.

Mayer, A. M.; Staples, R. C. (2002), Laccase: new functions for an old enzyme. Phytochemistry, 60, 551-565.

Nelson, N. (1994) A photometric adaptation of the Somogyi method for the determination of glucose. $J$. Biol. Chem., 153, 375-380.

Ohga, S.; Royse, D.J. (2001), Transcriptional regulation of laccase and cellulase genes during growth and fruiting of Lentinula edodes on supplemented sawdust. FEMS Microbiology Letters, 201, 111-15.

Palma, M. B. et al. (1996), Influence of aeration and agitation rate on the xylanase activity from Penicillium janthinellum. Process Biochemistry, 31, 141-145.

Pandey, A.; Selvakumar, P.; Soccol, C. R.; Nigam, P. (1999), Solid-state fermentation for the production of industrial enzymes. Current Sciences, 77, 49-162.

Raghavarao, K. S. M. S.; Ranganathan T. V.; Karanth; N. G. (2003), Some engineering aspects of solid-state fermentation. Biochemical Engineering Journal, 13, 127-135.

Reid, I.D.; Seifert, K.A. (1981), Effect of atmosphere of oxygen on growth, respiration, and lignin degradation by white-rot fungi. Canadian Journal Bothanical, 60, 252-260.

Slomczynsky, D., Nakas, J.P.,Tanenbaum, S.W. (1995), Production and characterization of laccase from Botrytis cinerea 61-34. Applied Environmental Microbiology, 61, 907-912.

Techapun, C. et al. (2003), Optimization of aeration and agitation rates to improve cellulase-free xylanase production by thermotolerant Streptomyces sp. Ab 106 and repeated fed-batch cultivation using agricultural waste. Journal of Bioscience and Bioengineering, 95, 298-301.

Thurston, C. F. (1994), The structure and function of Phanerochaete chrysosporium. Methods in Enzymology, 140, 19-26.

Waarishi, H., Valli, K., Gold, M. H. (1992), Manganese(II) oxidation by manganese peroxidase from the basidiomycete Phanerochaete chrysosporium. J. Biol. Chem., 267, 23683-95. 
Watanabe, K. (2002), Linking genetics, Physiology and ecology: and interdisciplinary approach for advancing bioremediation. Journal of Bioscience and Bioengineering, 94, 557-562.

White, N.; Boddy, L. (1992), Differential extracellular enzyme production in colonies of Coriolus versicolor, Phlebia radiate and Phlebia rufa: effect of gaseous regime. Journal Genecti Microbiology, 138, 2589-2598.

Received: August 15, 2005; Revised: May 05, 2006; Accepted: January 21, 2008. 